\title{
Disruptive Behaviours in the Class of the Foreign Language
}

\author{
Alma Muharremi \\ "Aleksandër Xhuvani" University, Elbasan, Albania \\ Faculty of Education Sciences, Department of Teaching Methodology \\ almamuharremi@gmail.com
}

\section{Doi:10.5901/jesr.2014.v4n4p0495}

\begin{abstract}
Disruptive behaviours in the class of the foreign language are disturbing for both the teacher and the students. This study aims to compare the mean disruptive behaviours in the classes of German and Albanian language. It observes twenty-nine students of the sixth grade, aged 11-12 years old, who studied German as a second foreign language. The general mean of the disruptive behaviours in the classes of German was much higher than in the classes of the Albanian language. The types of the disruptive behaviours in both classes differed very little. Applying group work and the CD-ROM technology may be useful in reducing the level of students' disruptive behaviour in the class of foreign language.
\end{abstract}

Keywords: Albanian language, German language, disruptive behaviour, type of disruptive behaviour, lower high education.

\section{Introduction}

After the changes in the "Law for the pre-university education", two foreign languages are being taught from the third grade to the thirteenth in the Albanian pre-university education system. It used to be one foreign language, but now in some schools a second foreign language was introduced in grades six to twelve. This second foreign language can be French, English or German.

Unlike English, French and Russian, the tradition for the German language is very new. It was traditionally taught in the high schools for foreign languages and in the German Language Department in the universities of Tirana and Elbasan. At the moment it is intensively taught in four high schools for foreign languages in Tiranë, Elbasan, Shkodër and Korçë. It is also taught in three schools in Tiranë, starting from grade six (schools "Fan Noli", "Avni Rustemi" dhe "Jeronim de Rada"); from grade five in two private schools - The Children's Village SOS in Tiranë and the school of Nehemia Foundation in Pogradec; and in some private and public schools -2 to 3 hours.

German as a second foreign language at "Sulë Harri" school in Elbasan was introduced in the school year 20132014, for students of grade six. The school has three sixth grades, two of which study French as a second foreign language, and one studies German.

Learning foreign languages aims for the linguistic, intellectual and cultural development of students, so that they become able to face daily situations and the learning process during their whole life. If offers them the opportunity to know and understand the way of thinking and behaving of the other people; facilitates communication between people in a diverse and multi-cultural world. It is based on the philosophy and the instructions of the Common European Framework of Reference for Languages, and on other curricula documents of the pre-university education in Albania. Learning of the German language in the Albanian pre-university system is based on the syllabus programme of the German language (2012).

Apart from the importance already given to the learning of a foreign language, there are no studies in Albania on the possible disruptive behaviours happening as result of the attitude towards the learning a foreign language.

Kingdon (1995) confirms that disruptive behaviours in the class of foreign language are problematic for the teachers. Thirteen of the teachers involved in the study made known their concerns about students' behaviours. The most frequent forms of disruptive behaviours were "Continuous refusal to work", "Aggressive behaviour towards the others" and "Refusal to follow teacher's instructions".

Researchers Jung and Boman (2003) compared the frequencies of students' disruptive behaviours in the classes of the German language to the behaviours encountered in the classes of mainstream schools. They observed four types of disruptive behaviours among forty-nine students aged nine to twelve, from grade four to grade seven. The percentages of disruptive behaviours were $25.38 \%$ in the classes of German language and $17.9 \%(t(43)=12.78, p=0.001)$ in the mainstream schools' classes. It was noted that students who displayed disruptive behaviours in the classes of the 
German language had the tendency to display the same behaviours in the mainstream schools' classes. Researchers make some suggestions on how to improve the teaching practices.

Disruptive behaviours affect the teaching/learning process for both the teachers and the students. This "leakage" reduces the class-work time of the students, which seems to affect their results. Researchers report that students have less time available for class-work, and their results are lower. The research shows that the level of the disruptive behaviours may affect negatively the results.

This study observed the students' behaviours in the classes of German and Albanian languages in order to measure the disruptive behaviours - aiming to compare the students' average disruptive behaviours in these classes, and the types of disruptive behaviour. Because of the students' perception that learning German is difficult, the prediction was that students display a higher average of disruptive behaviours in the classes of German language, than in classes of the Albanian language.

\section{The Method}

\subsection{Participants}

29 students of class VIC of the "Sulë Harri" school in Elbasan, Albania - aged 11-12 years old, 20 girls and 9 boys.

\subsection{Procedure}

The students' disruptive behaviours were recorded by direct observation during the classes of Albanian and German languages. The greatest advantage of the direct observation is that it provides direct data from the natural environment in which the behaviour is observed. During the study, efforts were made to create an environment as realistic as possible in class, so that the data obtained could reflect behaviours as real as possible.

Six types of disruptive behaviours were observed: non-immediate obedience to instructions; speaking without permission (without waiting for his/her turn); being noisy; looking around; touching the others; leaving the seat without permission. These behaviours were the most frequently encountered ones in both classes. This categorisation has been used by Sentelle (2003) and Yang \& George (1995).

The research team consisted of the researcher and his five assistants. The assistants were students of education, chosen in an open procedure and trained in a two-step process. They attended classes of Albanian and German languages, and each of them observed the behaviours of five students, keeping notes only of disruptive behaviours, if any. The observers were coded from 1-6 in each observation session, code they kept until the end of the research. They had disruptive behaviours recording cards, which contained the codes of the behaviours and the codes of the students. The data from the cards were entered into a summary table. The observation intervals were conducted during 10 classes of each language, lasting 5 minutes each, twice a week, during a period of five weeks. The observations in the class of the German language were conducted on the days it was scheduled (Tuesdays and Wednesdays), and the observations of the Albanian language classes were conducted in the same days.

The subjects were taught by two teachers. The teacher of the Albanian language was graduated as a Teacher of the Albanian Language and Literature, has been awarded the first degree of qualification with the "Very well" result, and has a working experience of twenty-one years. The teacher of the German language was graduated as a Teacher of the German Language, and has been working for three years.

Both classes were conducted in the same classroom, which is the room where students of group $\mathrm{VIC}$ always conduct classes.

\section{Results}

After 10 observations on each student in both classes, more disruptive behaviours were recorded in the class of the German language than in the class of the Albanian language.

Each observed subject displayed an mean of 3.84 disruptive behaviours (standard deviation $=3.79$, standard error mean .61) during the classes of the German language (see Table 1), and an mean of 1.57 (standard deviation $=1.38$, standard error mean .22) during the classes of the Albanian language. The fact that the deviation is high shows that there is a possibility to display disruptive behaviour in the class of the German language. The difference between the means for the total, obtained by the Paired Differences, is 2.26 (sig .000, 2-tailed). Regarding the types of the disruptive behaviours, the following were less frequently displayed during the classes of the Albanian language: "Non-immediate obedience to 
instructions" (mean difference .78; sig .000, 2-tailed), "Speaking without permission" (mean difference .84; sig .003, 2tailed), and "Being noisy" (mean difference .34; sig .051, 2-tailed). The differences between the means are not valid for statistics in the instances of "Touching the others" (mean difference .10; sig .291, 2-tailed), and "Leaving the seat without permission" (mean difference .23; sig .107, 2-tailed), because in both cases .sig is greater than .05. The only behaviour encountered more often during the Albanian language classes is "Looking around" (mean difference .05; sig .750, 2tailed), but it is not valid statistically because the sig. is greater than .05 .

Table 1: Mean of disruptive behaviours in the classes of German and Albanian languages

\begin{tabular}{|c|c|c|c|c|c|c|c|}
\hline Disruptive Behaviour & $\begin{array}{c}\text { Non-immediate } \\
\text { obedience to instructions }\end{array}$ & $\begin{array}{c}\text { Speaking without } \\
\text { permission }\end{array}$ & $\begin{array}{c}\text { Being } \\
\text { noisy }\end{array}$ & $\begin{array}{c}\text { Looking } \\
\text { around }\end{array}$ & $\begin{array}{c}\text { Touching } \\
\text { the others }\end{array}$ & $\begin{array}{c}\text { Leaving the seat } \\
\text { without permission }\end{array}$ & Total \\
\hline German classes & 1.1579 & 1.4474 & .4211 & .3421 & .1579 & .3158 & 3.8421 \\
\hline Albanian classes & .3684 & .6053 & .0789 & .3947 & .0526 & .0789 & 1.5789 \\
\hline
\end{tabular}

An interesting observation was that students who showed disruptive behaviours in the German classes had the tendency to show the same behaviours in the Albanian classes. The Pearson product-moment correlation between the proportion of pupils' disruptive behaviours in the German and Albanian classes shows that this result is correct $(r=.515, n=43$, $\mathrm{p}<.000)$.

The types of disruptive behaviours encountered more often in the classes of German differed very little from the ones encountered in classes of Albanian. The ranking of the averages of the disruptive behaviours during the German classes (See Table 2) showed that the most encountered behaviour in this class is "Speaking without permission" (mean $=1.4474$ ). The least encountered beahviour is listed "Touching the others" (mean $=0.1579$ ). The ranking of the averages of the disruptive behaviours during the Albanian classes (See Table 3) also showed that the most encountered behaviour in this class is "Speaking without permission" (mean $=.6053$ ). The last listed is "Touching the others" (mean $=.0526)$. The ranking is the same for both classes for behaviours listed: first, fifth, and sixth.

Table 2: Ranking of the means of the disruptive behaviours during the German classes

\begin{tabular}{|c|l|c|}
\hline No. & Type of behaviour & Mean \\
\hline 1 & Speaking without permission & 1.4474 \\
\hline 2 & Non-immediate obedience to instructions & 1.1579 \\
\hline 3 & Being noisy & .4211 \\
\hline 4 & Looking around & .3421 \\
\hline 5 & Leaving the seat without permission & .3158 \\
\hline 6 & Touching the others & .1579 \\
\hline
\end{tabular}

Tabela 3: Ranking of the means of the disruptive behaviours during the Albanian classes

\begin{tabular}{|c|l|c|}
\hline No. & Type of behaviour & Mean \\
\hline 1 & Speaking without permission & .6053 \\
\hline 2 & Looking around & .3947 \\
\hline 3 & Non-immediate obedience to instructions & .3684 \\
\hline 4 & Being noisy & .0789 \\
\hline 5 & Leaving the seat without permission & .0789 \\
\hline 6 & Touching the others & .0526 \\
\hline
\end{tabular}

\section{Discussion}

This study found out that the average of disruptive behaviours displayed by students in the classes of German language was higher than in the classes of the Albanian language. Data also showed that students who had a high average of disruptive behaviours in the classes of German language, had a high average in the classes of Albanian. The ranking of the six types of behaviours in both classes differed very slightly.

These findings match the findings of Miller's research (1996) in the classes of German language. Her research showed that disruptive behaviours included "Speaking", "Not being on task", and "Walking around". Kingdon (1995) further supported these results. The types of disruptive behaviours most often encountered by teachers were "Repeated 
interjections", "Strong and continuous refusal to work" and "Frequent refusal to follow basic teacher directions".

The frequencies of students' disruptive behaviours during classes of main subject were investigated in the researches of Alley et al (1990), Department of Education and Science and the Wales Office (1989), Jones et al (1995), Jones et al (1996), Lawrence and Steed (1986), Merret and Wheldall (1984), Wheldall and Merret (1988). The most frequently reported behaviours were "Speaking out of turn", "Avoiding work", "Idleness", "Disobedience", "Standing up". The Australian research has mainly the findings of this study (Burke and Jarman 1994; Johnson et al (1993), Oswald et al (1997). These studies listed "Speaking out of turn", "Idleness and avoiding work" and "Leaving the seat" as the most frequently encountered behaviours.

The results of this research have shown that although the types of disruptive behaviours were almost the same in the classes of German and Albanian, they appeared more often in the German class. The disruptive behaviours in class use up from the time allocated to the work of students and this has a negative effect in their learning and results.

Teachers may think that disruptive behaviours are discipline issues, but this is not always the case. It can often be a by-product of inappropriate learning activities (Smyth 1985). It also has to be noted that the most disruptive students in the classes of German were the same ones that were the most disruptive in classes of Albanian.

The teaching methods of the German language might need to be modified in order to improve students' behaviours. Use of inappropriate teaching activities may be reflected in the fact that students in general find it boring to learn a language (Holzknecht 1995; Jones 1995). In order to be successful, learning needs an obvious relation with primary knowledge and the real world.

So, a re-evaluation of the teaching methods might be necessary. A variety of teaching methods is needed, including group work, working with projects, modules, etc. Some researches suggested that group work and use of technology, such as CD-ROM may be useful in the classes of foreign languages (Magee 1999; Walker 1998). Magee found out that by using work group with language CD-ROMs, there were very few occurrences of computer and behaviour problems in class. She believed that the use of such programs kept alive the interest of students who were almost bored and inclined to display bad behaviour. But it is important that language programs are user friendly. The use of the programs may have a positive effect not only on the students' behaviour, but also on the attitude towards learning another foreign language. It has to be noted that not all language teachers have access to the technology.

In general students need to be in an encouraging environment that includes appropriate activities such as work group, in order to achieve success in teaching another foreign language. Understanding is better developed using audiovisual didactic aids, signs, mimic, demonstrations and projects, which generate certain meanings. These make possible for all students in an equal and differentiated way the linguistic experimentation, the critical and creative thinking; group work; the effective use of technology, the connection of the German language with the other subjects, they encourage communication and the use of ICT.

A distinguishing feature of teaching a foreign language should be the communicative teaching through practical activities, using authentic visual and listening aids (CD, DVD, and text), which are considered main sources of knowledge acquisition and of the development of the linguistic, social-cultural and pragmatic skills and expressions.

The research was limited because of some conditions which were out of the control of the researcher. The purposive nature of the sample restricted the generalisation of the results. The sample was limited because the class was the only one that learnt German as a second foreign language. The small size of the sample does not allow the generalisation of the results. Another restriction was that the German and Albanian languages were taught by different teachers.

Above all this study has shown that the averages of disruptive behaviours in the classes of German and Albanian languages differ significantly. Further research should focus in the investigation of disruptive behaviours in the classes of foreign languages. This will help clarify if the German language is particularly difficult for the students, or if studying of any subject in general causes disruptive behaviours.

\section{References}

Alley R, O'Hair, M. \& Wright, R. (1990). Student misbehaviours: which ones really trouble teachers? Teacher Education Quarterly, pp. $63-70$.

Burke, C. \& Jarman, K. (1994). Disruptive and anti-social behaviour in the middle years of schooling: approaching the primary-secondary divide. Unicorn, vol 20, no 2, pp. 52-57.

Department of Education and Science and the Welsh Office, (1989). Discipline in Schools: Report of the Committee of Enquiry chaired by Lord Elton. London: Her Majesty's Stationery Office.

Eggen, P. \& Kauchak, D. (1994). Educational psychology: classroom connections, USA: MacMillan College Publishing Company. Holzknecht, E. (1995). A survey of year 6-7 at a Lutheran primary school: attitudes to language learning, LOTE Links, vol 6, no 3. 
Johnson B, Oswald, M. \& Adey, K. (1993). Discipline in South Australian primary schools, Educational Studies, vol 19, no 3, pp. 289304.

Jones, C. (1995). Language courses are too hard, say students. LOTE Links, vol 6, no 3.

Jones K, Charlton, T. \& Wilkin, J. (1995). Classroom behaviours which first and middle school teachers in St Helena find troublesome, Educational Studies, vol 21, no 2, pp. 139-153.

Jones K, Ling Quah, M. \& Charlton, T. (1996). Behaviour which primary and special school teachers in Singapore find most troublesome, Research in Education, vol 55, pp. 62-73.

Jung, J. \& Boman, P. (2003). Comparison of disruptive behaviours in South Australian LOTE and mainstream primary school classrooms, Journal of Educational Enquiry, Vol. 4, No. 2, pp. 90-101.

Kingdon, M. (1995). Student behaviour management: addressing the issues for teachers of languages other than English, In R Conway \& J Izard (eds) Student behaviour outcomes: choosing appropriate paths. Selected papers in the Proceedings of the 1995 National Conference on the Behaviour Management and Behaviour Change of Children and Youth with Emotional and/or Behavioural Problems, Melbourne, Australian Council of Education Research, pp. 86-91.

Common European Framework of Reference for Languages, http://www.goethe.de/z/50/commeuro/

Lawrence, J. \& Steed, D. (1986). Primary school perception of disruptive behaviour, Educational Studies, vol 12, no 2, pp. $147-157$.

Law "For the pre-university education system in the Republic of Albania" - revised, (2010). Tirana. Albania.

Magee. VYG. (1999). Implementing co-operative group work and CD-ROMS into LOTE classrooms, Primary Educator, vol 5, no 4, pp. 24-29.

Merrett, F. \& Wheldall, K. (1984). Classroom behaviour problems which junior school teachers find most troublesome, Educational Studies, vol 10, no 2, pp. 89-92.

Miller, J. (1996). LOTE in primary school contexts, In Proceedings of the Joint Conference of the Educational Research Association, November 1996. Singapore: Singapore and Australian Association for Research in Education, pp. 25-29.

Oswald, M. Johnson, B. \& Whitington, V. (1997). Classroom discipline problems in South Australian government and independent schools: is there a difference? Research in Education, vol 58, pp. 59-69.

Sentelle, J. (2003). A multicomponent behavioral intervention for a diverse classroom, Dissertation, Presented in Partial Fulfillment of the Requirements for the Degree Doctor of Philosophy in the Graduate, School of The Ohio State University, pp. 62.

Smyth, WJ. (1985). A context for the study of time and instruction, In CW Fisher \& DC Berliner (eds) Perspectives on instructional time, New York: Longman, pp. 3-27.

The syllabus programme of the German language (2012). The National Curricula of the basic education, Tirana, Albania.

http://www.izha.edu.al/programet/Programe_lendore_ars_baze2013/Gjuhe\%20gjermane\%20-\%20Kl.3-9.pdf

Yang, K. M., \& George, S. (1995). The effects of Self - Evalutiaon, Self - Observation, and Self - Observation plus Self - Recording on the Occurrence of Disruptive Behaviors in Classroom: Extencion Study, ED 385 028, pp. 6.

Walker, ML. (1998). LOTE learned by computer, Primary Educator, vol 4, no 6, pp 1-3.

Wheldall, K. \& Merrett, F. (1988). Which classroom behaviours do primary school teachers say they find most troublesome? Educational Review, vol 40, no 1, pp. 13-27. 